\title{
Contributions Of Recreational Festivals In Spreading The Culture Of Peace Among Peoples
}

${ }^{*}$ Ph.D/ Yehia mostafa kamal

**Ph.D/ Ahmed taha helmy.

Abstract

The Research Aims to identify the role of recreational festivals in building and spreading a culture of peace among peoples, The study has a major question, which is defined in "What is the role of recreational festivals in spreading a culture of peace among peoples, This study was structured as a qualitative approach, The researchers selected the sample by Intentional method, which included (250) participants from the International Festival of Youth and Students, which was held between 12 - 22 October 2017 in the Russian city of Sochi, The researchers used a questionnaire to measure the culture of peace as a tool for collecting study data, The participants in the festival responded to the extent of understanding the concept of a culture of peace through their disapproval of exclusion, oppression and denial of the rights of others, the researchers recommend the, recreational festivals rganizing, youth meetings and exchanging delegations among countries in order to build a strategy of a culture of peace

Keywords . culture of peace. Festivals.

\section{Introduction}

Today, the world suffers from many conflicts and wars between rival forces, individuals, societies and aggressor states, which resulted several successive and accelerating waves in all spheres of life, (Heba ,2013), If all regions of the world are in need of peace, the Arab region is most in need to achieve the appropriate conditions for a culture of peace (Faten, Abeer, 2016)

No one denies seeing the evolution of Egyptians' behavior towards intensity and violence clearly unacceptable (Abdel Nabi, 2011), With it, societies should move to find a

*Lecture, Department of Recreation Sport, Faculty of Physical Education for Men, Helwan University

" Lecture, Department of Recreation Sport, Faculty of Physical Education for Men, Helwan University 
way out of the crisis and achieve social peace in society. (Noha, Nahla, 2011) Therefore, the majority of contemporary trends in the social and human sciences are concerned with studying the conditions, attitudes, values and roles of youth in society

A point raised by (Ali, 2012), refers to the concept of social peace is the compatibility of youth with the values and norms in society, as is a state of calm, homogeneity, cooperation, engagement and interdependence as well as the rejection of hostile and irrational behaviors of conflict and loss of security and the ability to exercise democracy and respect Law and freedom from violence and intolerance.

The culture of peace also includes a set of values, models of behavior, principles and lifestyles based on the most important foundations (92: 163), Include Renouncing violence, respecting life, adopting methods of peaceful coexistence, persuasion, social justice, democratic participation and meeting the development needs of future generations (Marwa, 2015)
It also respects cultural diversity, encourages international cooperation, develops awareness of the common destiny of mankind and human rights concepts, and recognizes the right of everyone to freedom of expression, opinion and access to information (Mohamed, Samira, 2017)

several scholars have examined forms of recreation are as diverse as festivals characterized by social atmosphere, It provides opportunities to get to know each other in their activities and to meet between groups, as well as the participation of groups with common interests in a fun and enjoyable atmosphere in addition to the development of social loyalty among participants and the strengthening of social relations through interaction between them during participation(EI hamahmy, Aida, 2001) (Tahani, 2001) (Samira, Enas, 2009)

Many believe that the real goal of spreading a culture of peace is to bring happiness to human life, especially if it uses cultural activities and exchanges that are an ideal way 
to develop friendship between people of different cultures and nationalities (Jamal, 2014)

The 19 th festival of youth and student (wfys) is a unique event, where young people from around the world unite to develop a vision for our planet, energetic and engaged young people from 180 countries, who have already been actively involved, the festival is organized by its founder, the world federation of democratic youth, which has consultative status with UNESCO and the national preparatory committee of the host country, the 2017 festival marks the seventieth anniversary of the event ،

the festival sporting programme is among its most important elements, football, hockey, skating, basketball, extreme and national sports, competitive gameing, so that anybody who wants to take part can do so irrespective of their level of physical fitness.

\section{Statement of the Problem}

The researchers point that recreational festivals are one of the elements of the culture of society, it is a experiences and directed to the behavior of individuals through participation in, programs, events and activities to achieve values of peace, especially solidarity, sharing and giving, as well as inclose the feelings of the audience and get rid of the emotions and excessive energies that Lead to violence, As well as enjoy recreational activities within recreational festivals, and get rid of the burdens resulting from the pressures of life occurs psychological balance, which is immune from extremism, as well as that the recreational festivals contain a container of cultures of dialects and traditions and others, and thus constitute an important carrier of culture among the owners of different cultures, and create opportunities Suitable for understanding each other, cultural acceptability and mixing.

Therefore, the researchers decided to spot light on the culture of peace and the mechanisms to achieve it and the implications of its disappearance from the social and personal behavior in Egypt, and how recreational festivals can contribute to the promotion of concepts of peace as a preliminary step to raise awareness of the need to 
renounce

violence, discrimination and hatred as the main entrance to a better and more secure and stable society

\section{Purpose of the Study}

The Research Aims to identify the role of recreational festivals in building and spreading a culture of peace among peoples

\section{Research questions}

The study has a major question, which is defined in "What is the role of recreational festivals in spreading a culture of peace among peoples

- What is the role of recreational festivals in spreading the concept of a culture of peace?

- What is the role of recreational festivals in spreading the culture of peaceful coexistence?

- What is the role of recreational festivals in spreading the values of acceptance of the other?

- What is the role of recreational festivals in promoting the values of dialogue and negotiation?

- What is the role of recreational festivals in social integration?
- Are there statistically significant differences between the responses of the respondents due to the variables

(gender, qualification, nationality, study)?

\section{literature review}

Nadera Nassif (2016) : Building A Peace Culture: Peace Education Possibilities In Schools In Lebanon A Qualitative Study, The study was aimed at: (1) assessing the principals' effective practices, (2) discussing the challenges of establishing peace in schools dominated by violence and hostility, The study used the convenience sampling method to select 10 principals from 10 Lebanese schools, The instrument for data collection was based on semi-structured phone interviews, The overall results from conducting the study revealed: (a) the efforts of school principals to act as natural peace leaders despite the limited resources that is provided to them by the Ministry of Education, and (b) the great necessity for a national peace education program to be integrated in the Lebanese school curricula. Three recommendations were 
suggested: (a) to provide a team that will work to create a national peace education program for Lebanese school curricula.

Sanjaya S. Gaur , Mandar Chapnerkar (2015) : Indian festivals: the contribution they make to cultural and economic wellbeing A case study of Ganapati festival, the paper aims to highlight an Indian festival's contribution to cultural and economic wellbein, This study utilizes a qualitative approach to analyze the impacts of Ganesh Chaturthi festival,The study shows that the Ganesh Chaturthi festival fosters national cohesiveness, promotes communal harmony, preserves family values, helps maintain national identity, revitalizes the economy and fosters cultural tourism.

Peter R. Wright, Peter M. Wakholi (2015) : Festival as methodology: the African cultural youth arts festival, Qualitative Research, The purpose this paper is to consider festivals as sites for inquiry and learning, The research employed a pluralistic approach to the inquiry drawing on critical Africancentred pedagogy, participatory action research, and performance as research inquiry. In total, 12 young people and six elders of diverse African heritage as well as two artists were participants in the research, The research revealed that the festival as a research methodology was both dialogic and performative and a rich site for the exploration of identity negotiation. Through these arts-based approaches the aesthetic elements often missed by traditional social science methods were highlighted as key in exploring acculturation socialistaion experiences and deconstructing exclusionist discourses emanating from the dominant culture.

\section{Research Methods and Design}

This study was structured as a qualitative approach, which is the traditional foundation of social science research, The study follows the case study method as one of the descriptive analytical methods

\section{Sample}

The researchers selected the sample by Intentional method, which included (250) 
participants from the International Festival of Youth and Students, which was held between 12 - 22 October 2017 in the Russian city of Sochi.

\section{Data collection tools}

The researchers used a questionnaire to measure the culture of peace as a tool for collecting study data

Processing and Analysis

Results

Table (1)

Frequencies, percentages and value of $Q 2$ for the responses of the research sample on the first Dimension "the concept of a culture of peace" $(n=250)$

\begin{tabular}{|c|c|c|c|c|c|c|c|c|c|c|}
\hline \multirow{2}{*}{ Phrases } & \multicolumn{2}{|c|}{ Disagree } & \multicolumn{2}{|c|}{ Neutral } & \multicolumn{2}{|c|}{ Agree } & \multirow{2}{*}{$\begin{array}{c}\text { Estimated } \\
\text { Degree }\end{array}$} & \multirow{2}{*}{$\begin{array}{l}\text { Estimated } \\
\text { Percentage }\end{array}$} & \multirow{2}{*}{$\mathrm{Q}^{2}$} & \multirow{2}{*}{ Rank } \\
\hline & $\%$ & $\mathbf{F}$ & $\%$ & $\mathbf{F}$ & $\%$ & $\mathbf{F}$ & & & & \\
\hline 1 & 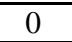 & 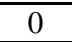 & 10.8 & 27 & 89.2 & 223 & 723.00 & 96.4 & 153.664 & 2 \\
\hline 2 & 0 & 0 & 11.6 & 29 & 88.4 & 221 & 721.00 & 96.13 & 147.456 & 3 \\
\hline 3 & 1.6 & 4 & 37.6 & 94 & 60.8 & 152 & 648.00 & 86.4 & 133.472 & 10 \\
\hline 4 & 92.8 & 232 & 6.4 & 16 & .8 & 2 & 730.00 & 97.33 & 399.008 & 1 \\
\hline 5 & 1.6 & 4 & 30.0 & 75 & 70.0 & 175 & 675.00 & 90 & 40.000 & 9 \\
\hline 6 & 1.6 & 4 & 16.4 & 41 & 82.0 & 205 & 701.00 & 93.47 & 274.664 & 5 \\
\hline 7 & 1.6 & 4 & 14.4 & 36 & 84.0 & 210 & 706.00 & 94.13 & 294.944 & 6 \\
\hline 8 & 5.6 & 14 & 13.6 & 34 & 80.8 & 202 & 688.00 & 91.73 & 255.872 & 8 \\
\hline 9 & 0 & 0 & 22.8 & 57 & 77.2 & 193 & 693.00 & 92.4 & 73.984 & 7 \\
\hline \multirow[t]{2}{*}{10} & 0 & 0 & 13.2 & 33 & 85.2 & 213 & 709.00 & 94.53 & 307.688 & 4 \\
\hline & \multicolumn{6}{|c|}{ sum } & 6994 & 93.25 & & \\
\hline
\end{tabular}

(Statistically Significant (Q2) Tested at A Level of $(0.05=5.99)$ Illustrated by Table (1), That Statistical Significance, Frequency, percentage and of the Responses of Research Sample, At Phrases of First Dimension (the concept of a culture of peace), ranged between (86.4\%) and $(97.33 \%)$, and the value of

(Q2) was significant to a response (Agree) for all phrases except phrase number (4) came in response (disagree).

The researchers confirm the responses of the participants in the festival in the extent of understanding the 
concept of a culture of peace through their disapproval of exclusion, repression and denial of the rights of others, which came first (97.33\%).In accordance with (Jamal huneidi 2014) argued that the concept of a culture of peace among students by confirmed the rejection of violence against the other and the absence of wars and conflicts in local and international communities

The phrase (1) came in second place (96.13\%), followed by the phrase (2) in the third place $(96.4 \%)$,(Yusuf Babma 2016), explains the basic standards of peace culture are achieved through respect for pluralism and cultural diversity, peaceful resolution of disputes, equality of rights and duties, and promotion of tolerance and solidarity. (Amanda, 2012)

Phrases No.(10) came at $(94.53 \%)$ in the fourth rank, followed by phrase (6) in the fifth rank, followed by phrase (7) $(94.13 \%)$ in the sixth place, This is highlighted by the United Nations that confirmed the culture of peace is fundamentally linked to mutual respect, understanding and cooperation at the international level, promoting democracy, development and respect for all human rights and fundamental freedoms, promoting sustainable economic and social development, as well as increasing transparency and accountability. (Amira, 2017)

Table (2) Frequencies, percentages and value of $Q 2$ for the responses of the research sample on the The second Dimension "peaceful coexistence" $(n=250)$

\begin{tabular}{|c|c|c|c|c|c|c|c|c|c|c|}
\hline \multirow{2}{*}{ Phrases } & \multicolumn{2}{|c|}{ Disagree } & \multicolumn{2}{|c|}{ Neutral } & \multicolumn{2}{|c|}{ Agree } & \multirow{2}{*}{$\begin{array}{c}\text { Estimated } \\
\text { Degree }\end{array}$} & \multirow{2}{*}{$\begin{array}{l}\text { Estimated } \\
\text { Percentage }\end{array}$} & \multirow{2}{*}{$\mathbf{Q}^{2}$} & \multirow{2}{*}{ Rank } \\
\hline & $\%$ & $\mathrm{~F}$ & $\%$ & $\mathrm{~F}$ & $\%$ & $\mathrm{~F}$ & & & & \\
\hline$\overline{1}$ & 4.8 & 12 & 31.2 & 78 & $\bar{~} 64.0$ & 160 & $\begin{array}{l}648.00 \\
\end{array}$ & 86.4 & 131.936 & 8 \\
\hline 2 & 9.2 & 23 & 16.0 & 40 & 74.8 & 187 & 664.00 & 88.53 & 195.176 & 5 \\
\hline 3 & 1.6 & 4 & 6.4 & 16 & 92.0 & 230 & 726.00 & 96.8 & 388.064 & 2 \\
\hline$\overline{4}$ & $\overline{0}$ & $\overline{0}$ & 22.0 & 55 & $\overline{78.0}$ & 195 & 695.00 & 92.67 & 78.400 & 3 \\
\hline 5 & 2.8 & 7 & 30.8 & 77 & 66.4 & 166 & 659.00 & 87.87 & 152.408 & 7 \\
\hline 6 & 3.2 & 8 & 28.0 & 70 & 68.8 & 172 & 664.00 & 88.53 & 164.576 & 5 \\
\hline 7 & 94.0 & 235 & 5.2 & 13 & 8 & 2 & 733.00 & 97.73 & 414.776 & 1 \\
\hline 8 & 6.0 & 15 & 32.8 & 82 & 61.2 & 153 & 638.00 & 85.07 & 114.296 & $\overline{9}$ \\
\hline \multirow[t]{2}{*}{$\overline{9}$} & 3.2 & 8 & 20.4 & 51 & 76.4 & 191 & 683.00 & 91.07 & 219.752 & 4 \\
\hline & \multicolumn{6}{|c|}{ sum } & 6110 & 90.52 & & \\
\hline
\end{tabular}

(Statistically Significant (Q2) Tested at A Level of $(0.05=5.99)$ 
Illustrated by Table (2), That Statistical Significance, Frequency, percentage and of the Responses of Research Sample on the second Dimension phrases "peaceful coexistence" ranged between $(86.4 \%)$ and $(97.73 \%), \%)$, and the value of (Q2) was statistically significant to a response (Agree) for all phrases except phrase number (7) came in response (disagree), The researchers confirmed that one of the foundations of peaceful coexistence is the renunciation of violence, acceptance of participatory and pluralistic, and openness to the other psychologically, intellectually and objectively, These results may be consistent with (Mohammed, Samira 2017), argued the importance of tolerance, and reject all forms of intolerance, and adopts awareness of the non-use of force as a means of change, and the development of peaceful methods in resolving conflicts.

The Phrases (3)came in second place $(96.8 \%)$, followed by Phrase (4) in the third place $(92.67 \%)$, followed by phrase (9) in the fourth place (91.07\%)

(Ali, 2012), (Abdul Rahman, 2017), agreed with (Sadiq, Mohammed, 2017), (Yousra, 2018) added that the role of cultural sports programs in providing students with the values of coexistence and peace through achieving various activities to promote tolerance, and Solve problems with careful thought and ratification of others in religion, maintain public security, judge colleagues fairly and impartially, negotiate to choose the best solutions proposed, perform the rights and grant the legal freedoms stipulated in the international constitutions.

Phrases (2) and phrase (6) came in the fifth and sixth rank $(88.53 \%)$, Tolerance through sport by spreading the values of peace by shaking hands after the completion of sports regardless of the result, dealing with affection and kindness, and seeking to spread friendship among all, and respect colleagues from other religions, (23: 313)

In accordance with Samia Baqir, Awatif Abdullah (2012) (16), Heba Ahmed (2013) (64), (Howaida Tawfiq, Ghada Wafik, Mohammed Suleiman (2018) (65)agreed that The effects of festivals on peaceful coexistence, renunciation of racism, as well as the need to develop religious motivation and the establishment of competitive festivals that help in spreading a culture of peace, and to achieve mutual understanding and respect, and to deepen national belonging and awareness. 
Table (3)

Frequencies, percentages and value of $Q 2$ for the responses of the research sample on the The third Dimension "dialogue and negotiation" ( $(\mathbf{n}=\mathbf{2 5 0})$

\begin{tabular}{|c|c|c|c|c|c|c|c|c|c|c|}
\hline \multirow{2}{*}{ Phrases } & \multicolumn{2}{|c|}{ Disagree } & \multicolumn{2}{|c|}{ Neutral } & \multicolumn{2}{|c|}{ Agree } & \multirow{2}{*}{$\begin{array}{c}\text { Estimated } \\
\text { Degree }\end{array}$} & \multirow{2}{*}{$\begin{array}{l}\text { Estimated } \\
\text { Percentage }\end{array}$} & \multirow{2}{*}{$Q^{2}$} & \multirow{2}{*}{ Rank } \\
\hline & $\mathrm{F}$ & $\%$ & $\%$ & $\mathrm{~F}$ & $\%$ & $\mathrm{~F}$ & & & & \\
\hline 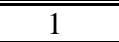 & 1.6 & 4 & 6.8 & 17 & 91.6 & 229 & 725.00 & 96.67 & 382.952 & 4 \\
\hline 2 & .8 & 2 & 10.8 & 27 & 88.4 & 221 & 719.00 & 95.87 & 344.888 & 6 \\
\hline 3 & 91.6 & 229 & 8.4 & 21 & 0 & 0 & 729.00 & 97.87 & 173.056 & 2 \\
\hline 4 & 0 & 0 & 12.8 & 32 & 87.2 & 218 & 718.00 & 95.73 & 138.384 & 7 \\
\hline 5 & 0 & 0 & 6.4 & 16 & 93.6 & 234 & 734.00 & 97.2 & 190.096 & 1 \\
\hline 6 & 4.8 & 12 & 14.4 & 36 & 80.8 & 202 & 690.00 & 92 & 256.928 & 9 \\
\hline 7 & 13.2 & 33 & 40.4 & 101 & 46.4 & 116 & 583.00 & 77.73 & 46.952 & 11 \\
\hline 8 & 92.4 & 231 & 7.6 & 19 & 0 & 0 & 731.00 & 97.47 & 179.776 & 3 \\
\hline 9 & 0 & 0 & 27.2 & 68 & 72.8 & 182 & 682.00 & 90.93 & 51.984 & 10 \\
\hline 10 & 1.6 & 4 & 8.0 & 20 & 90.4 & 226 & 722.00 & 96.27 & 367.904 & 5 \\
\hline \multirow[t]{2}{*}{11} & 1.6 & 4 & 18.8 & 47 & 79.6 & 199 & 695.00 & 92.67 & 251.912 & 8 \\
\hline & \multicolumn{6}{|c|}{ sum } & 7728 & 93.67 & & \\
\hline
\end{tabular}

(Statistically Significant (Q2) Tested at A Level of $(0.05=5.99)$

Illustrated by Table (3),

That Statistical Significance, Frequency, percentage and of the Responses of Research Sample on the third Dimension phrases "dialogue and negotiation " ranged between $(77.37 \%)$ and $(97.87 \%)$, and the value of (Q2) was statistically significant to a response (Agree) for all phrases except phrase number (3),(8) came in response (disagree) and the Phrase No. (5) came at $(97.2 \%)$ in the first place, The researchers confirm that the Dialogue between youth participating in the festival no matter how diverse their cultures and distances are, is a vital requirement and a common necessity to create mutual benefit opportunities, and Talking about agreement and difference through language, traditions, arts, beliefs and legacy of civilizations to gain trust and spread the spirit of understanding to open prospects of convergence and acceptance to make the chances of reconciliation and success closer and the possibilities of conflict and difference less.

Phrases (3) came in second place $(97.87 \%)$, and No. (8) in the third place $(97.47 \%)$ in the direction of response with (disagree), As seen by researches (Abeer, 2015), (Salah, 2018), agreed to the conditions of dialogue, abandonment of narcissism and selfishness, and away from the 
sectarian bias of opinion and respect for the other speaker and guidance to topics enriching culture Sporting, sharing information, respecting each other.

Phrases No. (1) came in fourth place $(96.67 \%)$, followed by phrase (10) in the fifth place $(96.27 \%$ ), and These results may be consistent with (Ahmed, 2013), (Jamal, 2014), (Ali, 2018) They point to the value of dialogue in the public interest and that it is necessary to solve problems, provide the appropriate environment for investing the efforts of youth, and provide a climate of trust and understanding among societies. It is clear that dialogue and negotiation may be an appropriate strategy to create a positive environment conducive to the development of the values of peace and promote the atmosphere, tolerance and social security, so the Negotiation and the conduct of its operations are also an important factor leading to a final decision by all parties to the negotiation process after the exchange of views on resolving a disputed problem and choosing the best one that is in the public interest. (Walaa, 2018).

Table (4)

Frequencies, percentages and value of $Q 2$ for the responses of the research sample on the The fourth Dimension " accepting the other " $(\mathbf{n}=\mathbf{2 5 0})$

\begin{tabular}{|c|c|c|c|c|c|c|c|c|c|c|}
\hline \multirow{2}{*}{ Phrases } & \multicolumn{2}{|c|}{ Disagree } & \multicolumn{2}{|c|}{ Neutral } & \multicolumn{2}{|c|}{ Agree } & \multirow{2}{*}{$\begin{array}{c}\text { Estimated } \\
\text { Degree }\end{array}$} & \multirow{2}{*}{$\begin{array}{l}\text { Estimated } \\
\text { Percentage }\end{array}$} & \multirow{2}{*}{$\mathbf{Q}^{2}$} & \multirow{2}{*}{ Rank } \\
\hline & $\%$ & $\mathbf{F}$ & $\%$ & $\mathbf{F}$ & $\%$ & $\mathbf{F}$ & & & & \\
\hline 1 & 0 & 0 & 6.0 & 15 & 94.0 & 235 & 735.00 & 98 & 193.600 & 1 \\
\hline 2 & 1.6 & 4 & 4.4 & 11 & 94.0 & 235 & 731.00 & 97.47 & 414.344 & 3 \\
\hline 3 & 6.0 & 15 & 20.0 & 50 & 74.0 & 185 & 670.00 & 89.33 & 193.400 & 9 \\
\hline 4 & 12.4 & 31 & 29.2 & 73 & 58.4 & 146 & 615.00 & 82 & 81.272 & 10 \\
\hline 5 & 8.0 & 20 & 7.6 & 19 & 84.4 & 211 & 691.00 & 92.13 & 293.384 & 8 \\
\hline 6 & 3.2 & 8 & 13.6 & 34 & 83.2 & 208 & 700.00 & 93.33 & 283.80 & 6 \\
\hline 7 & 0 & 0 & 10.4 & 26 & 89.6 & 224 & 724.00 & 96.53 & 156.816 & 5 \\
\hline 8 & 0 & 0 & 10.8 & 27 & 89.2 & 223 & 723.00 & 96.4 & 153.664 & 4 \\
\hline 9 & 94.0 & 235 & 6.0 & 15 & 0 & 0 & 735.00 & 98 & 193.600 & 1 \\
\hline \multirow[t]{2}{*}{10} & 1.6 & 4 & 18.8 & 47 & 79.6 & 199 & 695.00 & 92.67 & 251.912 & 7 \\
\hline & \multicolumn{4}{|c|}{ sum } & & & 7019 & 93.59 & & \\
\hline
\end{tabular}

(Statistically Significant (Q2) Tested at A Level of $(0.05=5.99)$

Illustrated by Table (4),

That Statistical Significance, Frequency, percentage and of the Responses of Research Sample on the fourth Dimension phrases " accepting 
the other " ranged between $(82 \%)$ and $(98 \%)$ and the value of (Q2) was statistically significant to a response (Agree) for all phrases except phrase number (9), came in response (disagree), The researchers confirm that the responses of the participants, which reflect their acceptance of the ideas and practices of the other individual different from them in opinion and thought, traditions, education, social and economic level, creed, language, color, gender and other differences and recognize their right to exercise all their rights.

The Phrases (1) ranked first $(98 \%)$, and these results may be consistent with the (Beazidou, 2016), (Hanan , 2017), (Walaa, 2018) agreed that the Values of accepting the other by respecting the difference and recognizing their acceptance, traditions and other differences in order to peaceful coexistence, in exchange for adherence to identity and avoid the concepts of racism and the desire to dominate and negative perceptions of the other that deny the existence of the other or trying to degrade or human existence
The Phrase No. (2) came in third place $(97.47 \%)$, followed by phrase (8) in the fourth place $(96.4 \%)$, followed by phrase (7) in the fifth place $(96.53 \%)$. These results may be consistent with (Mohammed, Hiam , 2016), (Ahmed, 2013), (Sadiq, Mounir, 2017), they agreed on the clarity of the concept of dealing with the other on the basis of equality and equality, and the opinion is the right of every human being, respect for difference of opinion, thought and belief, accepting positive criticism, and accepting others regardless of their social or financial level.

The Phrase (6) came in sixth place $(93.33 \%)$, followed by phrase (10) in the seventh $(92.67 \%)$, followed by phrase (5) $(92.13 \%)$ These results may be consistent with ( Faraj (2015), (Abeer , 2015), (Bassem, 2017) they agreed The conditions of acceptance of the other needs first of all self-esteem, honor and appreciation, cooperation, participation, acceptance of difference, tolerance, appreciation and coexistence, and to make students aware of the importance and respect for the other's freedom of thought and belief. (Cora, 2015) 
Table (5)

Frequencies, percentages and value of $Q 2$ for the responses of the research sample on the The fifth Dimension "social integration "

$(\mathbf{n}=\mathbf{2 5 0})$

\begin{tabular}{|c|c|c|c|c|c|c|c|c|c|c|}
\hline \multirow{2}{*}{ Phrases } & \multicolumn{2}{|c|}{ Disagree } & \multicolumn{2}{|c|}{ Neutral } & \multicolumn{2}{|c|}{ Agree } & \multirow{2}{*}{$\begin{array}{c}\text { Estimated } \\
\text { Degree }\end{array}$} & \multirow{2}{*}{$\begin{array}{l}\text { Estimated } \\
\text { Percentage }\end{array}$} & \multirow{2}{*}{$\mathrm{Q}^{2}$} & \multirow{2}{*}{ Rank } \\
\hline & $\%$ & $\mathbf{F}$ & $\%$ & $\mathbf{F}$ & $\%$ & $\mathbf{F}$ & & & & \\
\hline 1 & 4.8 & 12 & 17.6 & 44 & 77.6 & 194 & 682.00 & 90.93 & 226.592 & 11 \\
\hline 2 & 0 & 0 & 11.6 & 29 & 88.4 & 221 & 721.00 & 96.13 & 147.456 & 3 \\
\hline 3 & 0 & 0 & 4.8 & 12 & 95.2 & 238 & 738.00 & 98.4 & 204.304 & 1 \\
\hline 4 & 0 & 0 & 10.8 & 27 & 89.2 & 223 & 723.00 & 96.4 & 153.664 & 2 \\
\hline 5 & 1.6 & 4 & 12.0 & 30 & 86.4 & 216 & 712.00 & 94.93 & 320.864 & 5 \\
\hline 6 & 1.6 & 4 & 15.6 & 39 & 82.8 & 207 & 703.00 & 93.73 & 282.632 & 7 \\
\hline 7 & 3.2 & 8 & 16.4 & 41 & 80.4 & 201 & 693.00 & 92.4 & 255.752 & 8 \\
\hline 8 & 6.4 & 16 & 16.0 & 40 & 77.6 & 194 & 678.00 & 90.4 & 223.904 & 12 \\
\hline 9 & 1.6 & 4 & 14.8 & 37 & 83.6 & 209 & 705.00 & 94 & 290.792 & 6 \\
\hline 10 & 1.6 & 4 & 21.6 & 54 & 76.8 & 192 & 688.00 & 91.73 & 227.552 & 9 \\
\hline 11 & 1.6 & 4 & 22.8 & 57 & 75.6 & 189 & 685.00 & 91.33 & 217.832 & 10 \\
\hline \multirow[t]{2}{*}{12} & 0 & 0 & 14.0 & 35 & 86.0 & 215 & 715.00 & 95.33 & 129.600 & 4 \\
\hline & \multicolumn{6}{|c|}{ sum } & 8443 & 93.81 & & \\
\hline
\end{tabular}

(Statistically Significant (Q2) Tested at A Level of $(0.05=5.99)$

Illustrated by Table (5),

That Statistical Significance, Frequency, percentage and of the Responses of Research Sample on the fifth Dimension phrases " social integration " ranged between $(91.33 \%)$ and $(98.4 \%)$ and the value of (Q2) was statistically significant to a response (Agree) for all phrases, the Phrase (3) came first $(98.4 \%)$, followed by phrase (4) in the second order, followed by phrase (2) in the third rank, These results may be consistent with "(Ali (2012), (Abdul Aziz, 2013), (Ahmed, 2013), They confirmed that voluntary participation is a national duty through volunteering, and taking responsibility and belonging, rejecting negativity of all kinds, contributing to the building of an integrated society, ensuring self-reform by becoming a source of all good, and performing every citizen's duties towards others, fulfilling the rights of others, and exchanging benefits among the people of the country.

The phrase (12) came in fourth place (95.33\%), followed by the phrase (5) in the fifth rank, followed by the phrase (9) in sixth place, These results may be consistent with 
the study of (Taha, 2017), he referring to the recreational festivals are characterized by the inclusion of their activities on various programs including activities (sports, cultural, artistic, social), and aims to provide participants with the opportunity to achieve their needs and satisfy their desires their abilities, skills and talents, and provide opportunities to meet and exchange roles and build social relations to return to social participation.

These results may also be consistent with
(Mohammed, 2009), (Bassem, 2017), that agreed on The role of student activities in promoting the values of social tolerance, including participation that helping the community, and promoting the values of social cohesion and instilling the spirit of social responsibility, as well as the development of values of cooperation and teamwork, as well as instilling entrepreneurship and volunteerism.

Table (6)

Significance of differences between Gender males and females N. 250

\begin{tabular}{l|c|c|c|c|c|c}
\hline \hline \multirow{2}{*}{ Dimensions } & \multicolumn{2}{|c|}{ Female (103) } & \multicolumn{2}{c|}{ Male (147) } & Mean & \multirow{2}{*}{ t } \\
\cline { 2 - 6 } & Std. & Mean & Std. & Mean & Difference & \\
\hline \hline the concept of peace & 2.28 & 28.35 & 1.98 & 27.71 & $-.635-$ & $*-2.344-$ \\
\hline peaceful coexistence & 2.65 & 23.98 & 1.81 & 24.76 & .781 & $* 2.597$ \\
\hline dialogue and negotiation & 2.29 & 28.17 & 2.02 & 28.01 & $-.151-$ & $-.552-$ \\
\hline accepting the other & 2.43 & 30.76 & 1.99 & 31.02 & .263 & .940 \\
\hline social integration & 4.33 & 33.33 & 2.55 & 34.08 & .751 & 1.579 \\
\hline & 12.51 & 1.45 & 8.07 & 1.46 & 1.01 & .721 \\
\hline \hline
\end{tabular}

Statistically Significant (T) Tested at a Level of $(0.05=1.96)$

Illustrated by Table No.

(6), That Statistical Significant value of $(\mathrm{T})$, Indicating that there were differences between the responses of the research sample Between males and females to females in the first
Dimension, and there were Statistical Significant to male in the second Dimension, These results may be consistent with (Faten, Abeer, 2016) (Bassem, 2017). 
Table (7)

Significance of differences between Country Egyptian and foreigners N. 250

\begin{tabular}{l|c|c|c|c|c|c}
\hline \hline \multirow{2}{*}{ Dimensions } & \multicolumn{2}{|c|}{ Foreigners (22) } & \multicolumn{2}{c|}{ Egyptian (228) } & Mean & \multirow{2}{*}{ t } \\
\cline { 2 - 5 } & Std. & Mean & Std. & Mean & Difference & \\
\hline \hline the concept of peace & 1.33 & 27.36 & 2.18 & 28.04 & .671 & 1.416 \\
\hline peaceful coexistence & 2.17 & 23.14 & 2.20 & 24.57 & 1.429 & $2.920^{*}$ \\
\hline dialogue and negotiation & 2.16 & 26.27 & 2.05 & 28.25 & 1.977 & $4.298^{*}$ \\
\hline accepting the other & 1.51 & 29.77 & 2.20 & 31.02 & 1.249 & $2.598^{*}$ \\
\hline social integration & 2.89 & 32.18 & 3.42 & 33.93 & 1.744 & $2.309^{*}$ \\
\hline sum & 6.56 & 1.39 & 10.20 & 1.46 & 7.07 & $3.185^{*}$ \\
\hline \hline
\end{tabular}

(Statistically Significant (T) Tested at a Level of $(0.05=1.96)$ Illustrated by Table No.

(7), That Statistical Significant value of $(\mathrm{T})$, Indicating that there were differences between the responses of the research sample Between Egyptian and

\begin{tabular}{l|c|c|c|c|c|c}
\hline \hline \multirow{2}{*}{ Dimensions } & \multicolumn{2}{|c|}{ Humane (88) } & \multicolumn{2}{c|}{ Applied (162) } & \multirow{2}{*}{$\begin{array}{c}\text { Mean } \\
\text { Difference }\end{array}$} & \multirow{2}{*}{} \\
\cline { 2 - 6 } & Std. & Mean & Std. & Mean & \\
\hline \hline the concept of peace & 2.29 & 28.06 & 2.04 & 27.93 & $-.125-$ & $-.442-$ \\
\hline peaceful coexistence & 2.91 & 24.40 & 1.75 & 24.46 & .065 & .192 \\
\hline dialogue and negotiation & 2.46 & 27.86 & 1.93 & 28.19 & .328 & 1.083 \\
\hline accepting the other & 2.76 & 30.42 & 1.74 & 31.18 & .759 & $2.338^{*}$ \\
\hline social integration & 4.53 & 32.88 & 2.50 & 34.26 & 1.384 & $2.658^{*}$ \\
\hline sum & 13.41 & 1.44 & 7.70 & 1.46 & 2.41 & 1.553 \\
\hline \hline
\end{tabular}

(Statistically Significant $(\mathrm{T})$ Tested at a Level of $(0.05=1.96)$ Illustrated by Table No.

(8), That Statistical Significant value of $(\mathrm{T})$, Indicating that there were differences between the responses of the research
Foreigners to Egyptian, These results may be consistent with Shatha, et al, 2018), and may differ with (Abdul Rahman, 2017).

\section{Table. (8) \\ Significance of differences between Specialization Humane and Applied N. 250}


results of the study (Araf, 2015), (Asma, 2015), (Bassem, 2017).

\section{Conclusions}

Through the research objective, within the sample, procedures, and results obtained, the statistical results proved

- The participants in the festival responded to the extent of understanding the concept of a culture of peace through their disapproval of exclusion, oppression and denial of the rights of others, their readiness for the values of acceptance and appreciation of the rich diversity of cultures, as well as the promotion of tolerance in society

- The most important contribution of the festivals in spreading the values of peaceful coexistence through disapproval of violence and forces to solve problems, in addition to protection from the ideas of extremism and mental closure, and the commitment to settle conflicts by peaceful means, as well as the consolidation of the principles of public freedoms

- The most important contribution of recreational festivals in supporting the values of dialogue and negotiation was determined by respecting the difference of opinion and thought, and away from bullying

\section{Recommendations}

In the light of the results of the research results and within the framework of the sample the researchers recommend the following important, rganizing recreational festivals, youth meetings and exchanging delegations among countries in order to build a strategy of a culture of peace, constructive dialogue and coexistence, Work to develop the values of peace among young people through targeted programs, scientific plans and activities through which institutions work to acquire the values of a culture of peace and work to promote and develop them.

\section{References}

1- Abdel Aziz Hussein (2013); Professional Intervention of the Method of Organizing the Community for the Investments of Student Family Leaders in Marketing of Social Peace in the Egyptian Society Using Social Media, Journal of Studies in Social Work and Human Sciences, No. (35), Part (4), Higher 
Institute of Social Work, Port Said, Egypt.

2- Abdel Nabi Ahmed Abdel Nabi (2011) ; The effectiveness of a professional intervention program from the perspective of the general practice of social service in the development of youth awareness of the culture of social peace, Journal of Studies in Social and Humanities, vol (30), Helwan University, p. 1769 1771.

3- Abdul Rahman Ali Al-Juhani (2017); The educational role of the Islamic University in Medina in giving students tolerance grants, Journal of the Faculty of Education, Issue (176) Part (2), Faculty of Education, Al-Azhar University

4- Abeer Abdel Moneim Faisal (2015); A proposed program based on the method of dialogue in the subject of sociology for secondary students to develop the values of acceptance of the other, Journal of the Educational Society for Social Studies, Issue (70), Faculty of Education, Ain Shams University, Egypt.

5-Ahmed Abdel Hamid (2013); Planning Indicators for the Development of Social Peace Values among the Youth in the Slums, Journal of Studies in Social and Humanities, Issue (35), part (5), Faculty of Social, Fayoum University, Egypt
6- Ali Abdullah Mohammed (2012); A proposed concept from the perspective of general practice in social work to achieve social peace among university youth, International Conference 25 The future of social service under the modern civil state, Helwan University. P. 4402

7- Ali Yahya Nassef (2018); The effectiveness of the proposed program from the perspective of serving the group to develop a culture of peace among the members of the Scouting Group applied to a sample of youth in the Air Scout Association in Dakahlia Governorate, Journal of Social, Issue (59), Part (1), Egyptian Society of Social, Egypt .

8- Amanda S. Munroe (2012) : Peace Education Through Sport: Critical Pedagogy For Conflict Literacy, Thesis, Faculty of the Graduate School of Arts and Sciences of Georgetown University.

9- Amira Khairy Ali (2017) ; Proposed formulas to activate the efforts of Egyptian universities in spreading the culture of peace among their students, Suez Canal University as a model, Journal of the Faculty of Education in Educational Sciences, Volume (41), number (4), Faculty of Education, Ain Shams University. $\mathrm{P}$ 50,51

10-Araf Zaki Mohamed (2015); Tolerance as a variable to plan to address the phenomenon of violence 
among university youth, Journal of Studies in Social Work and Humanities, vol (38), part (13), Faculty of Social, Helwan University, Egypt

11-Asmaa Mostafa Mahmoud (2015); The trend of university youth towards social peace in the Egyptian society, Journal of Education for Educational, Psychological and Social Research, vol. (165), part (3), Faculty of Education, Al-Azhar University

12- Bassem Bakry Ibrahim (2017); The Role of Student Activities in Developing Citizenship Values among University Students, Egyptian Society of Social, No. (58), part (3), Egypt

13- Beazidou, Eleftheria, Botsoglou, kafenia (2016) : peer acceptance and friendship in early childhood : the conceptual between them, early child development and care, vol (186), num (10)

14- Cora Burnett (2015) : Assessing the sociology of sport: On Sport for Development and Peace, International Review for the Sociology of Sport, Vol. 50(4-5) 386 15- Farag Khairy Abdel Gayed (2015); University youth use of news sites and its role in promoting the trend towards acceptance of the other, Journal of Public Relations Research Middle East, Issue (9), Egyptian
Society for Public Relations, Assiut University, Egypt.

16- Faten Mohamed Abdel Hamid, Abeer Hassan Mostafa (2016): Promoting Peace Education for High School Students in Egypt, Journal of Educational, vol (45), Sohag University, p. 352

17- Hanan Ibrahim El Desouky (2017); The effectiveness of the ethical analysis approach in teaching history on the development of skills of value judgment and tolerance values and acceptance of the other among the preparatory stage students, The International Conference of the Educational Society for Social Studies, Tolerance and acceptance of the other, Volume 2, Educational Society for Social Studies, Ain Shams University, Egypt.

18- Heba Ahmed Abdel Latif (2013), Contributions of NGOs in spreading the culture of social peace among youth, Journal of Studies in Social Work and Science, vol (34), part (15), Faculty of Social, Helwan University. P 5569

19- Jamal Mohammed Al-Huneidi (2014); Analytical study of the views of students of the General Diploma in Education on aspects of the culture of peace and the obstacles to its application, Journal of the Faculty of Education, Volume (29), Issue (2), Faculty of Education, Menoufia University, Egypt. P 177 
20- Marwa Tohamy (2015) ; Violence among youth in Libya: A study in the crisis of citizenship and activating a culture of peace, Sudan journal, vol (6), Sudan Center for Research and Strategic Studies, sudan. P. 194

21- Mohamed El Zboun, Samira Hassan (2017) ; Proposed educational bases for Jordanian official universities to spread the culture of peace among students, Al - Manara Journal for Research and Studies, Volume (23), Issue (4), Jordan. P . 464

22- Mohamed Elhamahmy, Aida Abdel Aziz (2001); Recreation between theory and practice, Second Edition, Cairo. P. 112-116

23- Mohamed Hassan Mohamed (2009); The role of Palestinian universities in promoting the values of tolerance among their students, Master Thesis, Faculty of Education, Al-Azhar University,

24- Mohamed Sayed Abbas, Hiam Farouk Ibrahim (2016); Attitudes of university youth towards spreading culture of social peace, Journal of Social, Issue (55), Egyptian Society of Social, Egypt.

25- Nadera Nassif (2016) : Building A Peace Culture: Peace Education Possibilities In Schools In Lebanon A Qualitative Study, Dissertation, Faculty Of The School Of Education, Northcentral University. P.12
26- Noha Saady Ahmed, Nahla Khaled Mahmoud (2011); Using a proposed program in the service of the community to provide a culture of social peace for secondary school students, Journal of Studies in Social and Humanities, Helwan University. P. 787

27- Peter R. Wright, Peter M. Wakholi (2015) : Festival as methodology: the African cultural youth arts festival, Qualitative Research Journal Vol. 15 No. 2, , pp. 213-227

28- Sadiq Al-Hayek, Mohamed Mounir (2017); Developing the values of peace in children through sports, Journal for Research and Studies, Vol. 32, No. 1, Human and Social Sciences Series, Jordan.

29- Salah Abdullah Mohammed (2018); Requirements of developing the culture of electronic educational dialogue among graduate students, Faculty of Education, Assiut University, Journal of the Faculty of Education, Volume (34), Issue (2), Faculty of Education, Assiut University, Egypt.

30- Samira Mohamed Khalil, Enas Mohamed Ghanem (2009); Evaluating the management of the National Festival of recreational sports competitions compared to the management of the previous festival, The Third International Scientific Conference "Towards Better 
Investment of Egyptian and Arab Sports, vol (3), Faculty of Physical Education for Boys, Zagazig University. P 5

31- Sanjaya S. Gaur and Mandar Chapnerkar (2015) : Indian festivals: the contribution they make to cultural and economic wellbeing A case study of Ganapati festival, Worldwide Hospitality and Tourism Themes Vol. 7 No. 4, pp. 367-376

32- Shatha Abdel-Baqi El-Agaily, Amal Salah El-Din, Hanan AbdelGhaffar Attia (2018); The impact of university life on the development of a culture of community dialogue from the perspective of Amman Arab University students (descriptive study), Arab Journal of Arts and Humanities, No. 5, Egypt.

33- Taha Mohamed Gamal (2017); Attitudes of the pioneers towards participation in recreational festivals and their impact on increasing the demand for sports and recreational practice, International Journal of Physical Education and Sports Science, Helwan University

34- Tahani Abdel Salam (2001) ; Recreation and recreational education, First Edition, cairo. P 104

35- Walaa Mohamed Salah El Din (2018); The use of negotiation strategy in teaching sociology to develop a culture of peace and decision-making among secondary school students, Educational Journal,
Issue (65), Faculty of Education, Helwan University, Egypt. P 7 , 9

36- Yousra Mohamed Sayed (2018); A proposed unit for the development of coexistence skills and the trend towards acceptance of difference among secondary students studying psychology, Journal of the Educational Society for Social Studies, Issue (102), Faculty of Education, Ain Shams University, Egypt.

37- Youssef Babma (2016) : Analysis and evaluation of the concepts of a culture of peace in the national education curriculum in Côte d'Ivoire, Dissertation, Faculty of Graduate Studies, Holy Quran University, Sudan, p. 71

\section{8- wwW.russia2017.com}

\section{Assiut Journal For Sport Science Arts}

